\title{
Precautionary attachment on the shares under the Emirati Law (A Study in the Civil Procedures and Company Laws)
}

\author{
*Moustafa kandeel ${ }^{(1)}$, Tariq A. Kameel ${ }^{(2)}$, Amin Dawwas ${ }^{(3)}$ \\ $(1,2)$ College of Law \\ Al Ain University of Science and Technology, UAE \\ (3) Kuwait International Law School, Kuwait
}

*moustafa.kandeel@aau.ac.ae

\begin{abstract}
Distinguishing between the proceedings of the confinement on the nominal shares and bearer shares that is stated in the federal civil proceedings law number 11 of 1992 is useless. This is because of the issuance of the new federal commercial companies law number 2 of 2015 that includes nominative shares as the only shares to be confined according to the proceedings that are held for a particular confinement of the debtor's property with others (protective confinement). This kind of confinement supposes the existence of three parties: the first party is the distrainer creditor, the second party is the execution debtor shareholder, and the third party is the garnishee that is the company that exports the shares and the stock market where the shares are circulated. The nominative shares' confinement proceedings start by an announcement for the company that exports the shares and the stock market where the shares are circulated, then the confinement is announced for the execution debtor shareholder. In the confinement notification, the garnishee is asked for presenting a report of his debt of the debtor. If he does not do that, the garnishee shall be a subject for the legal penalty which imposes him to pay the debt. Signing the confinement leads the shares ad their attachments (the profits) to be under the control of a specific legal system according to which the confined shares and their profits' property stays for the shareholder. However, the shareholder has a constrained authority on the confined shares and the profits.
\end{abstract}

Keywords: Protective Confinement; nominative shares; Civil proceedings law; Commercial companies' law.

\section{Introduction}

It is known that the shares issued by the public shareholding company are the main traded commodity in the capital market. The shares stand as a title for their owner and they give him the right to earn his part of the benefits the company makes, to earn his part of the net assets of the company when it is liquidated, and to earn other rights in the public shareholding company. The shares owned by the shareholder in the shareholding company go under the public guarantee for the creditors; shares have a cash value defined by the market value of the share. This makes the shares subject to execution by force in order to pay a particular debt when the conditions that are stipulated by the legislator are fully met. 
The execution by force - execution by expropriation - is the most complicated way of the execution because the procedures that organize this type of execution go through various stages. In case the direct execution and the financial and physical compulsion do not work to make the debtor fulfill his obligation, this obligation turns into an amount of money- financial reimbursement- that is defined by the judiciary. In addition, if the obligation is an amount of money then the execution in this case and in the previously mentioned case is done by seizing the debtor's property in order to start the execution upon and to sell them to fulfill the creditor's rights.

Despite the fact that the Article 290 of the Emirati Federal Civil Procedures Law no. 11 of 1992, as modified by the law no. 10 of 2014 (hereinafter: the Civil Procedures Law), distinguishes between the procedures of seizure of nominal shares and bearer shares as each type has its own way of seizure that suits its nature. This distinction does not have an importance anymore under the new Emirati Federal Commercial Company Law no. 2 of 2015 (hereinafter: the Company Law) as Article (208) of it allows issuing the nominal shares only. Consequently, there shall be no need to explain the seizure system on the bearer shares.

According to Article 290/2 of the Civil Procedures Law, the nominal shares shall be seized in the way in which seizure of the property the debtor has with others (protective seizure) and this includes seizing the property's benefits till they are sold. This measurement is held because the nominal shares represent rights that shall not be merged within the same document that approves them. The shares shall not be transferred by the physical transference of the document employing them or by endorsement thereof only. Rather, the shares are seized in the share register and in the Financial Market where the shares of the company are listed ${ }^{(1)}$.

The system of precautionary attachment of the shares raises a lot of questions about the nature of the shares and the conditions of the right of the precautionary attachment of the shares, so what are these conditions? What are the procedures of the precautionary attachment of the shares? Are these procedures distinctive? And what are the impacts of the precautionary attachment of the shares?

To answer these questions, the research follows a descriptive analytical approach. This means that it clarifies and analyze the legal rules that deal with the mechanism of the precautionary attachment of the nominal shares in the Emirati legislation. The research aims to show to which extent these legal rules are in line with the nature of the commercial transactions that have flexible procedures. The research is divided into the following themes:

Theme One: The conditions of the right of the precautionary attachment of the shares.

Theme Two: The procedures of the precautionary attachment of the shares.

Theme Three: The impacts of the precautionary attachment of the shares.

1- Article (216) of the company law. 


\section{Theme One}

\section{The conditions of the right of the precautionary attachment of the shares}

Taken that the protective seizure has the same impacts of the executive seizure, the legislator puts two conditions for making the protective seizure ${ }^{(2)}$ : the first one is related to the creditor's right for which seizure is made (the first topic) and the second one is related to the condition of getting a permission for making the seizure (the second topic).

\section{Topic One}

\section{the creditor's right for which seizure is made}

In the first place, the creditor's right shall be an amount of money, so the protective seizure shall not be signed to make the debtor do a job ${ }^{(3)}$. In the second place, the creditor's right for which seizure is made shall meet the same conditions that shall be met in the executive seizure, namely: certain, due and specific i.e. of a particular amount.

These three descriptions have another form in case of the protective seizure ${ }^{(4)}$.

\section{First: the creditor's right for which seizure is made shall be certain}

There is no difficulty for meeting the condition of certainty if the seizure is made based on an executive bond. Generally, the right is certain if it is confirmed and undisputable ${ }^{(5)}$. This condition does not mean that the debtor shall not dispute the debt; however, it means that its existence shall not be seriously disputable and the creditor shall have the evidence of its existence $^{(6)}$.

If the person who asks for the protective seizure does not have an executive bond, there shall be a permission for making the seizure. For the judge to allow making the seizure, the right of the person who asks for the seizure shall be certain. This does not mean that it shall exist or it shall be undisputable, it means that there shall be an obvious reason for its existence in the debtor's responsibility. The judge who is asked to release a permission does not rule in the subject of the existence of the right, he seeks the apparent existence of the right and the final result does not restrict the judge later ${ }^{(7)}$.

Accordingly, if a serious dispute falls over the existence of the right before the judge who is

2- Dr. Fathi Wali: the mandatory execution in the commercial and civil articles, The Arab Nahda House, 1995 , provision 141 and what comes after it.

3- Dr. Fathi Wali: the previous source, provision 142.

4- Dr. Mohammad Abdulkhalik Omar: the execution principles, The Arab Nahda House,the fourth edition, 1974, provision 199.

5- Dr. Amina Alnimer: the procedures law (the third book) Alma'rif institution in Alexandria, 1982, provision 174.

6- Ibid.

7- Dr. Fathi Wali: previous source, provision 143, Dr. Mohammad Abdulkhalik Omar: previous source. 
asked to release the seizure permission, he shall refuse to release the seizure permission because of the absence of the condition of existence ${ }^{(8)}$.

\section{Second: the creditor's right for which seizure is made shall be due}

This means that the right shall not be a subject to possibility or related to a particular description ${ }^{(9)}$. The creditor's right shall be due; if it is delayed the execution process shall not be conducted before the due date. This is logical because if the right is not due, it shall not be asked for since this action deprives the debtor from the previously set due date. Accordingly, there shall not be an execution based on a rule that gives the debtor additional time to pay the debt based on Article 359 of the civil transactions law.

Third: the creditor's right for which seizure is made shall be specific, i.e. of a particular amount

Concerning this condition, it shows that the legislator mitigates the conditions of the right that shall be protectively seized. The right does not necessarily have to be accurately defined as in the case of the executive seizure, it is enough for the right to have an initial particular amount that is defined by the judge who releases the permission of the seizure. Whenever the right does not have a particular allocated amount, there is a need-to sign the seizure- to earn a permission from the judge in order to give a temporal estimation for the right ${ }^{(10)}$.

The reason of allowing the making of the protective seizure without waiting the allocation of the creditor's right in a final way is to avoid trafficking the debtor's money during this time. And the reason of requiring the temporal estimation of the creditor's right is to give the opportunity to use the methods that are organized by the legislator to decrease the total effect of the seizure. It aims to achieve balance between the value of the creditor's right and the value of the debtor's seized property ${ }^{(11)}$.

Article 254/2 of the Civil Procedures Law, as modified by the law no. 10/2014, and the last part of Article 258 thereof stipulate that the judge of immediate things shall order the seizure when the creditor has a judgment that entails a debt of a specific amount, the judgment itself shall not be an executive one.

\section{Topic Two}

\section{Getting a permission to make the seizure}

\section{First: the necessity of getting a permission to make the seizure}

To protect the debtor from signing the precautionary attachment of his shares without a reason,

8- Ibid.

9- Dr. Ashour Mabrouk: a brief in execution in the current procedures law, The Arab Nahda house, the second edition, 2004, provision 421.

10- Dr. Ahmad Hindi, Dr. Ahmad Khalil: the mandatory execution law, the university publishing house, 1999, p. 420.

11- Dr. Fathi Wali: previous source. Provision 175. Dr.Ashour Mabrouk: The mandatory execution in the Emirati law, UAE University publishing, 1996, provision 383. 
Articles 254/1, 258 of the Civil Procedures Law require the issuance of a permission from the judiciary to make the seizure if the creditor does not own an executive bond or if his debt is not specified in mount.

There is a necessity to distinguish between two cases: If the creditor has an executive bond, the protective seizure shall be signed without a permission provided that the bond employs a debt of a specific amount. If the creditor does not have an executive bond, however, he shall gain a permission from the judiciary to make the protective seizure.

This is justified based on the fact that the party that owns the whole (i.e. the executive seizure) shall have the less (i.e. the protective seizure $)^{(12)}$. Furthermore, the creditor who has an executive bond may prefer a protective seizure because it contains the element of surprise for the debtor in order to avoid the risk of not hiding or trafficking the money of the debtor ${ }^{(13)}$.

The Emirati legislator requires gaining a permission from the judiciary to sing the protective seizure in the case of the absence of the executive bond even if the person who requests the seizure has a non-executive sentence with a fixed debt of a specific amount (Article 254/2 of the Civil Procedures Law as modified by the Law no. 10/2014). This would be the case when the creditor has a sentence from the court of first instance and the sentence is still subject to an appeal and not described as an urgent executing one, or when the creditor has an executable sentence but another sentence is issued and cancels its execution.

\section{Second: Jurisdiction entitled to release the permission for the protective seizure}

The judge of the urgent issues is the one competent for releasing the permission of the seizure on what the debtor's owns with others, i.e. the company (Article 258 of the Civil Procedures Law). The request of getting the permission is a temporary, urgent request that does not affect the origin of the right ${ }^{(14)}$.

In case the creditor's right for which seizure is requested is subject to a lawsuit before the competent court, it is allowed to request the protective seizure from this court (Articles 252/1, $254 / 3$ of the Civil Procedures Law). The seizure request is related to the right claimed ${ }^{(15)}$.

However, the jurisdiction is held for the judge in whose department the money that is to be signed for seizure exist.

12- Dr. Ashour Mabrouk: Alwaseet in execution, previous source, provision 425. Dr.Mohammad Noor Shehata: the mandatory execution in UAE, Dubai Police academy, the second edition, no year of publication, provision 229.

13- Dr. Mahmoud Hashim: the rules of the mandatory seizure and its procedures in the procedures law, Abu Almajd publishing house, the second edition, 1991, p. 288.

14- Dubai cassation, June 2004, the group of rules, number 15, number188, p.1263, rights impugn, Dr. Ali Abdulhameed Turki: the explaination of the mandatory execution procedures under the law of the federal civil proceedings number 11 of 1992, the Arab Nahda house, the first edition, 2009, provision 450.

15- Dubai cassation, impugn number 163 of 1989, the group of rules, number 1, number 2, p. 261. Dr. Ali Abdulhameed Turki: previous source. 


\section{Third: The proceedings of getting the permission}

According to Articles 253, 254/1, 258 of the Civil Procedures Law, requesting the permission of making the protective seizure are the same like the orders proceedings on the pleas that are mentioned in Articles $140 \& 141$ thereof. The plea should include the required information in the pleas orders in general in addition to requesting the permission for making the protective seizure and the information that is specified in this request. The plea shall be reasoned and it shall include a complete explanation of the shares that are requested to be seized.

\section{Fourth: The judge's authority issuing the permission:}

The judge who is competent to release the permission for making the protective seizure has the authorities of the judge of urgent matters in releasing the plea orders; he has a wide discretionary authority in releasing the seizure permission ${ }^{(16)}$.

The judge has the right to refuse the request if it appears that the creditor's right does not exist or it is not due or if the person who asks for the protective seizure is ill-intentioned and he wants to cause a damage the debtor ${ }^{(17)}$. The judge has the right to order making the protective seizure for part of the debts only, i.e. those meeting all the conditions. He can also order the protective seizure under the condition of imposing the debtor to pay part of the debts before the seizure process and to give him a specific time to pay the whole debt. The judge may order the creditor to submit a guarantee ${ }^{(18)}$, he may as well put any other condition as long as the condition does not violate any text or legal principle ${ }^{(19)}$.

Unlike the general rules of issuing the orders on the pleas without hearing the litigants, the judge may - before issuing the order of making the protective seizure - make a brief investigation to be persuaded to issue his order if he finds the documents the creditor provides with the request lacking (Article 254/1 of the Civil Procedures Law).

In all cases, and before responding to the protective attachment request, the judge has the right to ask upon information, evidences or depositions that are proven by the oath if he deems necessary (Article 252/4 of the Civil Procedures Law). According to Article 140/2 of the Civil Procedures Law, the judge is not bound to give the reasons upon which he takes his decision concerning releasing the permission or not as long as this decision does not violate an order that is issued before in the same subject matter ${ }^{(20)}$.

It should finally be noted that the judge has no discretionary power if the judgment the creditor

16- Dubai cassation, June the 6th, 2004, the group of rules, number 15, number 188, p. 1263, Dubai Cassation, April 21st 2008, impugn number 198 of 2007, Dubai cassation, June the 4th, 2006, the group of rules, number 17, number 151, p. 1047.

17- Dr. Fathi Alwali: the previous source, provision 153, Dr. Ahmad Abu Alwafa: the execution procedures in the civil and commercial articles, Alma'rif institution in Alexandria, the second edition, 1971, provision 212.

18- Dubai cassation, June 10th, 1993, the group of rules, number 4, number 109, rights impugn number 71 of 1993.

19- Dr. Fathi Wali: previous source, Dr. Ahmad Abu Alwafa: Previous source.

20- Dr. Amina Alnimer: previous source, provision 416. 
has entails a fixed amount of money, the judge shall order the protective seizure (Articles 254/2 $\& 258$ of the Civil Procedures Law) ${ }^{(21)}$.

\section{Fifth: Authoritative order issued by judge and complains of:}

The order of making the protective seizure issued by the judge is a timely verdict that is issued in a plea, then it can be enforced urgently by the power of law despite the ability of grievance or the grievance itself. It shall also be considered void if it is not presented for execution within thirty days of its issuance ${ }^{(22)}$.

The grievance is made based on the general rules in the orders on the pleas (Article 141/1 of the Civil Procedures Law). It is allowed to raise the grievance in the claim on the seizure's validity, in any stage of the claim and that occurs by the proceedings by which the provisional orders are raised (Article 141/3 of the Civil Procedures Law) ${ }^{(23)}$.

The grievance rules either the support of the order, the modification of the order, or the cancellation of it. This ruling is a subject to appeal using the normal ways of appeal (Article 141/4 of the Civil Procedures Law).

\section{Theme Two}

\section{The procedures of the protective seizure of shares}

As previously mentioned, the shares are seized according to the system of seizing the debtor's property that others have. This type of seizure involves three types of people: the first is the creditor who requests the seizure procedures, the second is the debtor (i.e. the shareholder), and the third is the company that issues the shares and the stock market in which the company is listed (hereinafter: the other party with whom the shares are seized). Seizure of what the debtor has with others goes through two stages: it starts as protective seizure and, then, it moves to be executive seizure.

The procedures of seizing the shares start by a notice of seizing the debtor's shares to be sent to the other party with whom the shares are seized (the first topic), then the seizure is informed to the shareholder in a specific time (the second topic). As the other party with whom the shares are seized (the company and the stock market) is responsible for reporting the debtor's property, it shall do this or it shall be a subject to the legal penalty (the third topic).

21- Dubai cassation, March 19th, 2006, civil impugn number 288 of 2005, the group of rules, number 17, number 76, p.517.

22- Dr. Ashour Mabrouk: the mandatory execution in the Emirati law, a previous source, provision 391.

23- Dr. Ahmad Abu Alwafa: previous source, provision 213. 


\section{Topic One \\ Notice of seizure to the other party with whom the shares are seized (the company and the stock market}

According to Article 259 of the Civil Procedures Law, seizing the debtor's right with others occurs upon an order that is signed by the judge and totified the other party (the company and the stock market). This notice shall not be preceded by a request to the debtor to pay or a notice to him of the executive document if it exists. This seizure shall not also be preceded by a request to the third party (the company and the stock market) to pay ${ }^{(24)}$. This notice of seizure shall be summoned by the execution officer. It shall include the following information:

[1] Definition of the original amount of the debt and the expenses for which shares are seized: it shall have a specific amount of money either temporarily or permanently. This is in the interest of the other part (the company and the stock market); it enables him to figure out the amount of money that shall be deposited in the court's safe in case he wants to cancel the seizure. He also shall be notified of the amount of money he shall pay if he violates his commitment for the seizure by paying the debtor (the shareholder) ${ }^{(25)}$. It is also beneficial for defining the court competent to deal with the claim of the seizure evidence in the cases where this claim shall be raised ${ }^{(26)}$.

[2] Definition of the seized shares in an absolute way and ordering the other party (the company and the stock market) not to pay the debtor (the shareholder) or to deliver the shares to him. Accordingly, the other party is officially notified not to pay to the shareholder, and if he pays despite of that, he shall pay again ${ }^{(27)}$.

[3] Number of the file or claim of seizure and the creditor's name and his domicile or the place where he works. In case he does not have a domicile or a place of work in the country, he should specify a chosen domicile in the district of the court where the execution happens. In case the right for which seizure is made is claimed before a court and the seizure order is issued from this court, the number of the claim shall be revealed. In case the seizure is conducted based on an order that is issued by the immediate issues' judge, the number of the request of seizure shall be revealed ${ }^{(28)}$.

[4] Ordering the other party (the company and the stock market) to report to the court the property the debtor has with him and to inform the court that the order of seizure is executed within fourteen days from notice.

24- Dr. Fathi Wali: previous source. Provision 164.

25- the previous source: Dr. Amina Alnimer: provision 334.

26- Dr. Azmi Abdulfattah: the rules of the mandatory seizure in the procedures law, The Arab Nahda house, 1998, p. 503.

27- Dr. Azmi Abdulfattah, previous source, p. 504.

28- Dr. Abdulfattah Mubarak: a brief in the mandatory execution in the UAE, Ithra' for distribution and publishing (Jordan), first edition, 2010, p. 185. 
If the seizure order does not include the data mentioned in the first and second provisions, the seizure is void and each one who has an interest can assert this voidance (Article 260 of the Civil Procedures Law). Failure of the statement of the chosen domicile of the creditor shall not annul the notice of the seizure; it can rather be notified of all papers relating to the seizure in accordance with Article 8/8 of the Civil Procedures Law. Finally, ignoring the fourth statement does not cause any voidance of the notice. Instead, it results in making the third party not committed to report. In this case, the third party shall be ordered to report by a separate notice ${ }^{(29)}$.

With regard to the way of notice of the seizure for the third part, it shall happen according to the general rules of summon mentioned in Articles 8 and 9 of the Civil Procedures Law.

\section{Topic Two}

\section{Notifying the debtor (the shareholder) of the seizure}

The seizure is made and its effects appear at the moment of notifing the seizure order on the other party (the company and the stock market). Since the debtor (the shareholder) is the original part of the seizure, he shall be notified of the seizure so he has the knowledge about the subject and takes the necessary measures either by paying the debt or disputing the correctness of the seizure $^{(30)}$. In addition, the debtor shall know the real reason that prevents the other party from paying the him his right so he does not ask him to pay the debt without fruitlessly. Accordingly, the seizure notice is not part of the seizure procedures but a later procedure that follows the seizure itself $f^{(31)}$.

In accordance to Article 261/1 of the Civil Procedures Law, the seizure shall be notified for the debtor (the shareholder) after it is notified for the other party (the company and the stock market). This notice shall include the following information:

[1] Making of seizure and its date.

[2] Stating the judge's order upon which the seizure occurs.

[3] Stating the amount of money for which seizure is made.

[4] Stating the share that is seized.

[5] Stating the name of the creditor, his domicile, and his workplace in the country. In case he does not have a domicile or a workplace, he has to assign a chosen domicile in the district of the court where the execution occurs.

Article 261/1 of the Civil Procedures Law does not define a time to notify within, it also does not mention the penalty of not notifying which may cause some creditors to postpone the notification

29- Dr. Mohammad Abdulkhalik Omar, previous source, provision 513.

30- Dr. Ahmad Abu Alwafa: previous source, provision 217.

31- Dr. Fathi Wali, provision 167, Dr. Ahmad Hindi and Dr. Ahmad KHalil: the previous source, p. 446. 
especially that the seizure's effects start at the moment the other party is notified of it. However, the legislator binds the creditor to file a lawsuit against the correctness of the seizure within eight days from announcing the seizure on the other part (the company and the stock market) or the seizure shall be void (Article 261/2 of the Civil Procedures Law). This is why the researcher recommend that the Emirati legislator handles this issue especially that Article 255 of the 1980 Civil Procedures Law draft necessitated notifying the debtor of the seizure within eight days of the other party's notification of the same or the seizure shall be $\operatorname{void}^{(32)}$.

\section{Topic Three}

\section{Reporting the debtor's property}

\section{First: Definition of the report and the reason of it:}

Seizing what the debtor has with others occurs at the moment of announcing the seizure to others. Given the fact that it is generally difficult for the creditor to determine whether or not the other party is owing something to his debtor (the shareholder), there is a need for a procedure that aims to clarify the nature of the relation between the the other party and this debtor. Is there a debt relation between them? What are its conditions? To achieve this goal, the legislator requires the other party to present a report about the property the debtor has with him.

This report is especially important for defining the elements of this property in the cases where the seizure is general ${ }^{(33)}$. Obviously, the legislator wants to make it easy for the creditor to make the seizure.

\section{Second: the necessity of the report and the one who is committed to it:}

The other party or the ones who act on his behalf is responsible for above mentioned report ${ }^{(34)}$. The other party shall report once he is notified of the seizure. Notice of the seizure shall include an order on him to present such a report based on the rules of the Article 259/d of the Civil Procedures Law or he is required to present this report in a later paper.

The other party shall be committed to this report at all circumstances even if he is not indebted to the debtor (Article 263/3 of the Civil Procedures Law) or if the debt is disputed ${ }^{(35)}$. The other party is obliged to report even if the creditor does not have an executive title or a non-executive judgment ${ }^{(36)}$. Furthermore, the secret of the other party's job does not exempt him from reporting (Article 236/3 of the Civil Procedures Law).

The other party shall be committed to present the report to the entity that orders the seizure (Article 259/d, 236/1 of the Civil Procedures Law), i.e. the office of case management in the court that orders the seizure.

32- Dr. Ashour Mabrouk: the mandatory execution in UAE, article 316.

33- Dr. Fathi Wali: previous source, provision 169.

34- Dr. Fathi Wali: previous source, provision 171.

35- Dr.Mohammad Abdulkhalik Omar: previous source, provision 521, Dubai cassation, Dec. 2006, civil impugn number 221 of 2006. Dr. Ali Abdulhameed Turki: an explanation for the mandatory execution procedures, provision 501.

36- Dr. Fathi Wali: previous source, provision 170. 


\section{Third: Exemptions from reporting:}

In accordance to the Article 261/1 of the Civil Procedures Law, the other party (the company and the stock market) is exempted from reporting its debts in the following cases:

a. if an amount of money that equals the debt and its expenses for which seizure is sought is deposited in the court's safe, whether by the debtor or not. In this case, the seizure shall be made on this deposited amount (Article 249 of the Civil Procedures Law).

b. if an amount of money that is estimated by the executing judge based on the debtor's request (the shareholder) is deposited in the court's safe. In this case, the seizure shall be made on this deposited amount of money (Article 250 of the Civil Procedures Law).

c. if the other party (the company and the stock market) deposits the debtor's property in the court's safe either by himself or based on the debtor's request. In this case, the court that orders the seizure shall notify the creditor and the debtor (the shareholder) immediately about the deposit (Article 262/3 of the Civil Procedures Law).

For the exemption to occur in this last case, the following conditions shall be met ${ }^{(37)}$ : Firstly, the deposit shall be accompanied with a memo that is signed by the other party (the company and the stock market) of the seized items that he had, the seizures dates, the creditors' names and addresses, the documents upon which the seizures occurred, and the debts for which such seizures are made (Article 262/2 of the Civil Procedures Law). Secondly, the deposit shall be enough to pay the creditor's debt (Article 262/4 of the Civil Procedures Law).

\section{Fourth: Time of repot:}

The other party (the company and the stock market) shall report within seven days of making the seizure (Article 263/1 of the Civil Procedures Law).

\section{Fifth: Report types and its procedures:}

In case the other party (the company and the stock market ) does not admit the debt, he shall present a negative report; otherwise, he shall present a positive report. The data differ from type to another:

The first type: the negative report:

The report is negative in two cases ${ }^{(38)}$ : The first case happens when there is no previous or current relation between the other party (the company and the stock market) and the debtor (the shareholder). In this case, it suffices that the other party declares this fact ${ }^{(39)}$. The second case happens when there is a previous relation between the other party and the debtor (the shareholder). In this case, the other party shall present a report that shows the reason of the termination of the relationship and the termination date (Article 263/1, civil proceedings). The other party shall present the papers that support his report in both cases.

The second type: the positive report:

The report is positive in case the other party declares that he has control over the debtor's shares.

37- Dr. Amina Alnimer: previous source, provision 359.

38- Dr. Azmi Abdulfattah: previous source, pp. 531-532.

39- Dr. Ahmad Hindi, Dr. Ahmad Khalil: previous source. 451. 
According to Article 263/1 of the Civil Procedures Law, such report shall include the following data $^{(40)}$ :

- The value of the seized shares.

- A detailed memo of the shares the debtor has with the other party.

- The document that gives the shareholder a right vis-a-vis the company (the memorandum of association - subscription)

- $\quad$ The previous seizures of the shares under his control.

To prevent any possible conspiracy between the other party and the debtor (the shareholder), the other party shall deposit all the documents that support the data mentioned in the report at the moment of presenting the report. If he does not have any documents, he is not committed to any deposition ${ }^{(41)}$.

\section{Sixth: Disputing the report}

Normally, the other party reports his actual debts and no one could dispute this report. However, the other party may not report the truth which affects the creditor's rights as well as the debtor's ${ }^{(42)}$. One of them may file a case against the other party to reveal the true relation between the debtor and the other party. According to Article 265 of the Civil Procedures Law, the dispute against the other party report is filed before the entity that orders the seizure. Given that this case belongs to the substance of the execution litigation, it goes under the procedural system for the general rules of the substance litigations.

\section{Seventh: Penalty of dialing to report:}

According to the general rules, if the other party does not provide the above said report on due date or if he provides am insufficient report, the creditor shall have the right to damages (Article 266/4 of the Civil Procedures Law).

In addition, Article 266/1 of the Civil Procedures Law includes a special penalty in such case, i.e. the other party has to satisfy the creditor's right for which seizure is sought. For this reason, the legislator gives the creditor the right to file the so-called "personal obligation case" that follows the regular procedures ${ }^{(43)}$.

[1] Conditions of the "personal obligation case": Article 266/1 of the Civil Procedures Law stipulates the conditions of binding the other party to satisfy the creditor's right. These are: The first condition: the creditor must have an executive title: this means that the creditor must meet all the conditions for taking his right whether the seizure occurs based on this title or the creditor gains it after the seizure ${ }^{(44)}$.

40- Dr. Mohammad Abdulkhalik Omar: previous source, provision 522. Dr. Ahmad Abu Alwafa: previous source, provision 228, Dr. Ashour Mabrouk: Alwaseet in the execution, previous source, provision 359.

41- Dr. Fathi Wali: previous source, provision 171.

42- Dr. Ahmad Hindi, Dr. Ahmad Khalil: previous source, p. 451.

43- Dubai Cassation, November the 4th, 2001, the group of rules, volume 12, number 118, p. 784, rights impugn.

44- Dr. Amina Alnimer: previous source, provision 360. 
The second condition: the creditor must have a benefit from signing the penalty: if the creditor gains his right from the debtor (the shareholder) or from another other party, he shall not have the right to ask for signing the penalty. Despite that and based on Article 266 of the Civil Procedures Law, the creditor has the right to ask the other party for the expenses of the claim and the reimbursements of any delay in delivering the report ${ }^{(45)}$. If the creditor is paid part of his right, he will have the right to ask the other party for the left part only ${ }^{(46)}$.

The third condition: the creditor must ask the court for signing the penalty; the court cannot decide the penalty on its own. Otherwise, the court would rule of what the litigants do not ask for and this is unacceptable.

The fourth condition: one of the three situations that are mentioned in Article 266/1 of the Civil Procedures Law should be available ${ }^{(47)}$. These are:

The first situation: if the other party does not provide a report of his debt in a legal way. The second situation: if the other party delivers a fake report.

The third situation: if the other party hides the documents that should be deposited to support the report.

[2] the court competent to see the "personal obligation case" and its litigants:

Article 266/1 of the Civil Procedures Law does not mention which court is competent to see the case of binding the other party to satisfy the creditor's right in case he violates the conditions of the report. Some jurists argue that this case is within the competency of the execution judge as it is an objective dispute in the execution ${ }^{(48)}$. The present writer supports this opinion. This is in line with the general rule that makes all objective disputes in the execution within the competency of the execution judge unless the legislator states anything else.

Regarding the litigants, the claimant in this case is the creditor; the defendant is the other party. The debtor does not interfere in this case as he must be away from it. However, he can be part of the claim if the other party's violation includes delivering a fake report ${ }^{(49)}$.

[3] procedures of filing the "personal obligation case"

According to Article 266/1 of the Civil Procedures Law, the personal obligation case is filed in the regular situations of filing claims. This means that it is filed in a paper that is deposited in the cases management office in the competent court (Article 42 of the Civil Procedures Law). The time of the claim is not mentioned in the text of the law. The jurisprudence argues that the creditor has the right to file this claim at any time as long as the right is not prescribed. However, the delay in filing the claim may be interpreted as a waiver. As for the

45- Dr. Mohammad Abdulkhalik Omar: previous source, provision 536, Dr. Ashour Mabrouk: the mandatory execution in UAE, provision 329.

46- Dr. Ahmad Abu Alwafa: previous source, provision 244.

47- Dr. Fathi Wali: previous souce, provision 174 , dr. Amina Alnimer: previous source, provision 360.

48- Dr. Mohammad Abdulkhalik Omar: previous source, provision 538, Dr. Azmi Abdulfattah: previous source, provision 807.

49- Dr. Fathi Wali: previous source, provision 174, Dr. Ahmad Abu Alwafa: previous source, provision 245. 
evidence, the general rules shall apply to this case ${ }^{(50)}$.

[4] the judgment in the "personal obligation case" and its effects:

If the previously mentioned conditions are met, the court shall order the other party to satisfy the creditor's right for which the seizure is conducted.

The court shall give such order even if it is proved that the other party is not indebted for the creditor's debtor or if such debt is found to be less than the creditor's right for which the seizure is sought ${ }^{(51)}$.

Besides, the creditor does not have to prove any damage due to the other party's conduct. Indeed, damage is presupposed to be caused by the other party ${ }^{(52)}$.

However, the court has a large discretionary power: it may order the other party to satisfy the whole right of the creditor for seizure is sought or only part of it based on the other party's conduct as well as all the surrounding circumstances of the case ${ }^{(53)}$. In all events, the court shall rule the other party to pay the case expenses and the damages resulting from his delay of delivering the report (Article 266/1 of the Civil Procedures Law). Such rule clearly makes the other party indebted vis-à-vis the creditor. This rule is considered as an executive title. The creditor may use it to request the seizure of the other party property. In case there is more than one creditor and the rule is issued for one of them, the rest of the creditors do not get benefit of it and they do not share the creditor favored by the rule in the right he gains from the other party ${ }^{(54)}$. The judgment that is made in this case goes under the general rules of appeal of judgments that are issued in the objective disputes of execution. Whether the judgment is appealable or not depends on the value of the claim, i.e. the value of the debt that the other party is supposed to pay. In addition, the appeal court's judgment is subject to challenge before the court of cassation based on the general rules ${ }^{(55)}$.

\section{Theme Three}

\section{The effects of the precautionary attachment of the shares}

There are two main effects of the precautionary attachment of the shares: the first one has to do with the objective right for which the seizure is sought, in this case the seizure will interrupt the prescription ongoing for the good of the debtor (the shareholder) and the other party (the company and the stock market) (the first topic). And the second one has to do with the property to be seized and its attachments, the share and its attachments (the profits) shall go under a

50- Dr. Azmi Abdulfattah: previous source, ps. 807-808, Dr. Mohammad Abdulkhalik Omar: previous source, 539.

51- Dr. Fathi Wali: previous source, provision 174, Egyptian civil impugn, 21st Dec. 1939, Omar's group, 3-36-18.

52- Dr. Ahmad Abu Alwafa: previous source, provision 245.

53- Dr. Mohammad Abdulkhalik Omar: previous source, provision 537.

54- Dr. Fathi Wali: previous source, provision174, Dr. Ahmad Abu Alwafa: previous source, provision 246.

55- Dubai Cassation, Dec. 17th 2006, civil impugn number 221 of 2006. Dr. Abdulhameed Turki: previous source, provision 651 . 
special legal system (the second topic) $)^{(56)}$.

Topic One: The effect of the seizure on the objective right (interruption of the prescription) According to Article 484 of the Emirati Civil Transactions Code, prescription is interrupted in case the right is claimed before a court or by any legal procedure that is asserted by the creditor to ask for his right.

Given that the seizure is a legal procedure that is conducted by the creditor to gain his right, this will lead to the interruption of prescription ongoing for the benefit of the debtor ${ }^{(57)}$. Signing the seizure on the shares by seizing the property that the debtor has with others (i.e. notice of the seizure on the other party) leads to the interruption of the ongoing prescription for the benefit of the other party (the company and the stock market) against the debtor (the shareholder) and the interruption of the ongoing prescription for the benefit of the debtor (the shareholder) against the creditor ${ }^{(58)}$. This effect occurs even though the creditor does not have an executive title ${ }^{(59)}$.

\section{Topic Two}

\section{The effects of the seizure on the shares and their attachments (subject of the shares and their attachments to a special legal system)}

Signing the seizure on the shares is followed by subjecting the shares and their attachments (the profits) for a special legal system in order to achieve the goal of the seizure which is paying the debt for the creditor. According to this special legal system, the property and the profits of the seized shares stay the debtor's (the shareholder's) ownership. However, this ownership is constrained in order to achieve the goal of the seizure which means that any disposition of the shares shall not be effective vis-a-vas the creditor and all similar persons. Besides, the debtor's power of getting the shares' profits is constrained.

\section{First: the property and the profits of the seized shares stay the debtor's (the shareholder's) ownership}

This leads to the following objective and procedural results:

[1] the objective results ${ }^{(60)}$ :

[a] the debtor (the shareholder) has the right to dispose of the seized shares without considering that as an act of dispassion of other's property. This act is considered intact between the parties; they shall bear all the consequences of the dispassion. However, such dispassion is not enforceable against the creditor and any one that acts on its behalf.

56- Dr. Ahmad Abu Alwafa, provision 168, 263 and what follows, 337 and what follows, Dr. Azmi Abdulfattah, p. 306 and what follows, 361 and what follows, 581 and what follows.

57- Dr. Fathi Wali, provision 212, Dr. Ashour Mabrouk: the mandatory execution in UAE, provision 277.

58- Dr. Amina Alnimer: previos source, provision 338, Egyptian civil impugn, Apr. 30th, 1975, the appeal rules of 26, p. 283.

59- Dr. Ahmad Abu Alwafa: previous source, provisions 257, 265.

60- Dr. Ahmad Abu Alwafa, provision 246, Dr. Fathi Wali, provision 214, Dr. Azmi Abdulfattah, p. 308 and what follows, Dr. Wajdi Ragheb: memos in the legal execution, no publisher, 1986, p. 241. Dr. Ashour Mabrouk: the mandatory execution in the UAE, provision 277. 
[b] the debtor (the shareholder) has the right to take the necessary protective measures to protect the seized shares. He also has the right to ask the other party to pay him. To protect the creditor's right, however, such payment of the debt by the other party shall occur as a deposit in the court's safe (Article 262/1 of the Civil Procedures Law) ${ }^{(61)}$.

[2] the procedural results:

[a] the seized shares stay within the general guarantee for all the creditors of the shareholder; any such creditor can sign a seizure on the same shares.

[b] when the seized shares are sold through the judiciary, the price replaces the shares in fulfilling the creditors' rights. If any amount of money is left after paying the creditors' rights, the left money is for the debtor (the shareholder).

[c] in case the seizure procedures are waived or cancelled for any reason, the legal act the debtor (the shareholder) does concerning the seized shares becomes effective retroactively, the debtor may assert it confronting everybody in an ex post facto from the date of doing it.

\section{Second: the debtor's (the shareholder's) disposal of shares is unenforceable}

[1] definition of the unenforceability:

Unenforceability in this regard means that all legal acts the debtor (the shareholder) does on the seized shares shall not be enforceble in confrontation of the creditor and those who act on his behalf. Accordingly, these acts do not prevent the continuation of the execution proceedings as the creditor starts them regardless any acts on the seized shares and without the need for issuing a judgment of the unenforceability of these acts ${ }^{(62)}$.

[2] scope of the unenforceability:

(a) the scope of the unenforceability in terms of acts:

In principle, the unenforceability touches all legal acts of the debtor (the shareholder) as long as they may hurdle the process of achieving the goal of the seizure. This applies to the following acts $^{(63)}$ :

1- the acts that lead to transferring the property of the seized shares from the debtor to somebody else: whether they are with a compensation like selling or exchanging or without a compensation like the will and the donate.

2- the acts that causes a bad impact on the normal creditor: these acts lead to rights in rem like the protective mortgage. These acts can worsen the normal creditor's position. As the mortgaged creditor has priority, the right of the normal creditor goes under threat.

In all cases, in order not to enforce the mortgage or the disposal made by the debtor, such mortgage or disposal shall not have a fixed date before the seizure ${ }^{(64)}$.

61- Egyptian civil Impugn, Feb. 26th 1970, the appeal rules of 21, p. 56, Jan. 31st 1975 of 8, p. 14, Dec. 12th 1957 of 8, p. 103.

62- Dr. Wajdi Ragheb: previous source, p. 310. Dr. Fathi Wali: previous source, provision 215.

63-Dr. Ahmad Abu Alwafa: previous source, provision 294. Dr. Azmi Abdulfattah: the mandatory execution rules, ps. 311-312.

64- Dr. Fathi Wali: previous source, provision 218. Dr. Wajdi Ragheb: previous source, p.248. 
(b) the scope of the unenforceability in terms of persons:

In principle, the unenforceability of the debtor's acts is determined for the benefit of the creditor even if he is a normal creditor and the person who wins the auction:

1- the creditor seeking the seizure of the shares, whether he is a normal one or he is not the one who starts the proceedings ${ }^{(65)}$. In case of multiple creditors, some acts may be enforced in confrontation of the first creditor seeking the seizure but not against the second one provided that the conditions of enforcing them against others are met after the first seizure and before the interference of the second creditor ${ }^{(6)}$.

2- the buyer in the auction (the one who wins the auction): the reason why these acts are unenforceable in confrontation of the buyer in the auction is to encourage those who have the desire to buy the shares to participate in the auction; otherwise, the seized shares would be sold in a cheap price.

Except the persons mentioned above, no one has the right to assert the unenforceability of the disposal of the seized shares. Accordingly, this unenforceability may not be invoked by the debtor (the shareholder), the one to whom the shares are disposed of, or the normal creditor who does not sign the seizure on these shares ${ }^{(67)}$.

\section{Third: constraining the shareholder's authority in gaining the seized shares' profits}

The seizure is not limited to the seized shares only, it also includes the profits of these shares. In fact, this is a general rule that applies to the seized money regardless of its nature ${ }^{(68)}$.

Based on that, the rule states that the seizure also includes the profits of the seized shares through all the duration that it takes until they are sold; the profits are considered seized by the force of law and without the need for any independent measure of seizing them ${ }^{(69)}$.

This rule is important because it helps fulfilling the goal of execution. Such execution applies not only to the shares seized but also to their profits ${ }^{(70)}$. Besides, this rule will not encourage the debtor to make disputes and hurdling the execution proceedings: If the profits were not seized along with the shares, the debtor would delay selling the seized shares as long as possible to get as much benefit of them is possible ${ }^{(71)}$. That's why the seized shares' profits are also seized even if a judgment halting execution is issued ${ }^{(72)}$. The profits seized include all due profits throughout the seizure period until the shares are sold.

65- Dr. Ahmad Abu Alwafa: previous source, provision 295.

66- Dr. Wajdi Ragheb: previous source, p.249.

67- Dr. Fathi Wali: previous source, provision 217.

68- Compare: Dr. Mohammad Abdulkhalik Omar, previous source, provision 465, Dr. Abdulbasit Jami'e and Dr. Amal Alfazayry: execution in the commercial and civil articles, Alma'rif institution in Alexandria, 1991, provision 275.

69- Dr. Fathi Wali: previous source, provision 223, Dr. Azmi Abdulfattah: previous source, p. 317.

70- Dr. Wajdi Ragheb:previous source, p. 252.

71- Dr. Fathi Wali: previous source, provision 223.

72- Dr. Azmi Abdulfattah: previous source, p. 318. 


\section{Conclusion}

The research ends up with the following results and recommendations:

\section{First: results:}

[1] Article 290 of the Civil Procedures Law distinguishes between the seizure proceedings of the nominal shares and the bearers' shares. However, this distinguish is no longer important under Article 208 of the Company Law that recognizes nominal shares only. According to Article 290 of the Civil Procedures Law, the seizure of nominal shares occurs in the way of seizing the debtor's property with others (protective seizure) and this type of seizure suggests the existence of three parts: the first one is the creditor who takes the seizure measures, the second one is the debtor, and the third is the other party i.e. the company and the stock market that control the shares seized.

[2] For signing the precautionary attachment of the shares, the Emirati legislator conditions the creditor's right to be an amount of money, certain and due. The Emirati legislator also requires getting a permission from the judiciary to make the seizure.

[3] The proceedings of seizing the shares start by seizing what the debtor has with the other party and this occurs through a notice to the shareholding company and the stock market where these shares are traded, then the debtor (the shareholder) is informed of the seizure. In the seizure issue, the other party (the company and the stock market) shall report the property the debtor has with him; otherwise, the other party shall be punished by imposing him to pay the debt to the creditor.

[4] Making the seizure on the shares leads to interruption of the prescription duration of the right by the other party in confrontation of the debtor (the shareholder) and interruption of the prescription duration of the right for the benefit of the debtor (the shareholder) in confrontation of the creditor.

[5] Making the seizure on the shares causes the shares and their attachments (the profits) to follow a special legal system according to which the seized shares' property and profits stay with the debtor (the shareholder). However, the shareholder's power on this property is constrained, his acts in the shares are not enforceable against the creditor and those who act on his behalf. Besides, this power does not include the shareholders' right to gain the shares' profits.

Second: Recommendations:

[1] The researcher suggests that Article 290 of the Civil Procedures Law shall be changed to include only the proceedings of seizing the nominal shares so the Article matches what is stated in Article 208 of the Company Law that recognizes nominal shares only.

[2] The researcher suggests that Article 254/2 of the Civil Procedures Law shall be changed in order not make it possible to make the protective seizure without permission from the judiciary if the creditor seeking the seizure has a non-executive judgment provided that 
it relates to a fixed debt. This would be in line with Article 319 of the Egyptian Civil Procedures Law.

[3] According to Article 261/1 of the Civil Procedures Law, the debtor (the shareholder) shall be notified of the seizure after notifying the other party (the company and the stock market). However, this Article does not state a particular time during which the notice shall occur; it does not also mention the penalty for not notifying which may lead some creditors to delay the notice of the debtor especially that the seizure's effects are valid at the moment of notifying the other party of the seizure. This is why the researcher urges the Emirati legislator to take this issue into consideration.

[4] Article 266/1 of the Civil Procedures Law does not define the court competent to see the claim of imposing the other part for paying the debt in case it does not present a report. In order to avoid any conflict about jurisdiction, the researcher proposes that the execution judge shall be defined by the Emirati legislator as the competent authority in this regard. The reason standing behind this proposal lies in the fact that such claim is an objective dispute in execution that fall within the competency of the execution judge. 